KRYSTYNA M. BŁESZYŃSKA

ORCID 0000-0003-3456-7542

Pedagogium - Wyższa Szkoła Nauk Społecznych

$w$ Warszawie

MAŁgorzata OrŁowSKa

ORCID 0000-0002-6387-1124

Akademia WSB

w Dąbrowie Górniczej

\title{
SENIORZY W CYBERPRZESTRZENI. MIĘDZY STEREOTYPEM A RZECZYWISTOŚCIĄ
}

\begin{abstract}
AвSTRACT. Błeszyńska Krystyna M., Orłowska Małgorzata, Seniorzy w cyberprzestrzeni. Między stereotypem a rzeczywistościa [Seniors in Cyberspace. Between Stereotype and Reality]. Studia Edukacyjne nr 56, 2020, Poznań 2020, pp. 153-166. Adam Mickiewicz University Press. ISSN 1233-6688. DOI: $10.14746 /$ se.2020.56.8

Today, stereotypically seniors are assigned many negative traits. One of them is their lack of digital competences, which in consequence leads to their exclusion from modern social life. Given that modern Western societies are rapidly aging, this problem is becoming a social issue that needs to be addressed. A significant part of society must not be allowed to live as outcasts. In this situation, a question arises whether contemporary seniors are definitively excluded, or is age not an apparent premise in their case, and the problem lies elsewhere? The analysis of the collected empirical material revealed that the variable determining the level and type of social participation in virtual society is not age, but the level of education. Therefore, contrary to the prevailing views, seniors are not at risk of information exclusion and it is difficult to consider them as digital immigrants. Contrary to stereotypes, seniors are more distant, selective and pragmatic; independence allows them not to imitate culture and lifestyles, but to create them in contrast to the generation of their grandchildren.
\end{abstract}

Key words: seniors, cyberspace, digital competencies, lifestyles

\section{Wprowadzenie}

Jednym z największych wyzwań pojawiających się przed społeczeństwami ponowoczesnymi są procesy starzenia się ich członków oraz wiążące się z tym problemy: deficyt wykwalifikowanych pracowników, rosnące obciąże- 
nia systemów ubezpieczeń społecznych oraz konieczność zapewnienia seniorom opieki medycznej i pielęgnacyjnej.

Odpowiadając na wyzwania epoki, WHO proklamowała lata 20202030 jako Dekadę Aktywnego Starzenia Się, wskazując kierunki działań niezbędnych dla poprawy jakości życia osób starszych. Do najważniejszych zaliczono zapobieganie dyskryminacji osób starszych oraz społecznemu wykluczeniu i marginalizacji, zwiększenie ich podmiotowości, niezależności życiowej i uczestnictwa społecznego, jak również poprawę niezbędnej tym osobom opieki i asortymentu usług ${ }^{1}$. Realizacja owych celów związana jest ze zmianą paradygmatu opieki nad seniorami oraz przejściem od sytuowania starzejącej się osoby w roli pasywnego adresata działań pomocowych i opiekuńczych ku zwiększeniu jego zdolności życia niezależnego. Do pryncypiów drugiego z wymienionych paradygmatów zaliczają się społeczna i zawodowa reaktywizacja seniorów, wzrost ich podmiotowości i gotowości ponownego przyjęcia odpowiedzialności za własne życie, jak również bardziej intensywne wykorzystywanie możliwości Internetu dla samodzielnego zaspokajania potrzeb życiowych (komunikacja, zwiększenie bezpieczeństwa osobistego, dostęp do opieki medycznej, rozrywki i informacji, zakupy, bankowość, czy teleopieka). Istotnym warunkiem realizacji owych rozwiązań jest jednak gotowość osób starszych do posługiwania się w życiu codziennym współczesnymi technologiami, zwłaszcza Internetem, jak również posiadanie przez nich odpowiednich do tego rodzaju działań kompetencji.

Predyspozycje seniorów w powyższym zakresie bywają jednak przedmiotem wątpliwości o zróżnicowanej argumentacji. Tezy cyfrowego wykluczenia seniorów uzasadniane bywają wpływem czynników kulturowo-społecznych (jak zacofanie technologiczne starszego pokolenia, kulturowe role dziadków i babć, czy wycofywanie się starszych osób z życia społecznego), biomedycznych (ograniczone z wiekiem zdolności percepcyjne i uczenia się, mniejsza sprawność manualna) i ekonomicznych (gorsza sytuacja finansowa osób pozostających na emeryturze). Nie bez znaczenia jest ekstrapolacja obserwowalnego zjawiska społecznej marginalizacji seniorów na relacje władzy i siły w cyberprzestrzeni².

Mając na względzie powyższe, ważne i konieczne wydaje się podjęcie analiz pozwalających na rozpoznanie stopnia, celów, form i uwarunkowań wykorzystywania nowych mediów (reprezentowanych tu przez Internet) przez pokolenie współczesnych seniorów.

${ }^{1}$ Decade of Healthy Aging (2019). WHO; https://www.who.int/docs/default-source/ documents/decade-of-health-ageing/decade-ageing-proposal-en.pdf?sfvrsn=b0a7b5b1_12 [retrived: 14.09.2019]; Decade of Healthy Ageing (2020-2030), (2019b). WHO; https:/ /www.who. int/ageing/decade-of-healthy-ageing [retrived: 14.09.2019].

${ }_{2}^{2}$ Z. Błeszyńska, Wolność i władza w sieci, [w:] Potencjały relacji sit w cyfrowym społeczeństwie wiedzy, red. L. Zacher, Warszawa 2018, s. 55-73. 


\section{Teoretyczne podstawy podjętych badań}

Procesy starzenia się są naturalnymi prawidłowościami rozwojowymi. Kategorie starości i człowieka starego są jednak konstrukcjami społeczno-kulturowymi i niejednokrotnie ulegały redefinicji, odnosząc się nie tylko do biologicznych zmian w organizmie, lecz także zmian usytuowania podmiotu $\mathrm{w}$ strukturach życia społecznego ${ }^{3}$. Obecnie, zgodnie $\mathrm{z}$ ustaleniami $\mathrm{WHO}^{4}$, przyjmujemy, iż starość rozpoczyna się około 60. roku życia i obejmuje etapy: fazę wieku starszego (60 - 75), fazę wieku starego (75 - 90) oraz fazę głębokiej starości (90+). Okres ten cechuje spadek kondycji zdrowotnej i fizycznej, osłabienie zdolności adaptacyjnych i funkcji psychicznych (zwłaszcza poznawczych), zmiany relacji i pełnionych ról społecznych, jak również zmiany $\mathrm{w}$ sposobie widzenia siebie i świata (spadek samooceny i poczucie bycia niepotrzebnym, utrata poczucia sensu życia). Procesy owe mają jednak zróżnicowany przebieg i stopień nasilenia u poszczególnych osób. Obok czynników genetycznych, dużą rolę w kształtowaniu ich dynamiki odgrywają stopień i formy podejmowanych przez seniora aktywności, jego tendencja do utrzymywania lub ograniczania kontaktów społecznych, tworzone sieci społeczne, jak również chęć i zdolności dostosowania się do wymagań środowiska. Interakcje między wzmiankowanymi wymiarami wyznaczają indywidualne strategie radzenia sobie ze starością. Pole wyboru seniora obejmuje przy tym dwie możliwości: określenie własnej sytuacji w kategoriach nowych wyzwań i możliwości oraz podjęcie aktywnych form radzenia sobie ze starością bez wycofywania się z życia społecznego i ograniczania form uzyskiwania satysfakcji życiowej, lub skupienie się na doświadczanych trudnościach i ograniczeniach, rezygnacja z poszukiwania satysfakcji życiowej oraz wycofanie z uczestnictwa społecznego w zamknięty krąg życia rodzinnego lub samotności ${ }^{5}$.

Pierwsza wymieniona jest strategią aktywną, nastawioną na dalszy rozwój, zachowanie i/lub redefinicję dotychczasowych wartości i stylu życia, odkrywanie nowych możliwości, jak również dookreślenie własnej osoby w nowych warunkach. Strategia druga ma charakter pasywny, a jej podstawowym celem jest redukowanie sytuacji postrzeganych jako stresujące lub zagrażające dotychczasowemu obrazowi JA podmiotu. O ile jednak strategia aktywna, skłaniając seniora do „wymyślenia siebie na nowo”, przyczynia

${ }^{3}$ Ch. Phillipson, Capitalism and the Construction of Old Age, London 1982.

${ }^{4}$ Decade of Healthy Aging (2019a). WHO; https://www.who.int/docs/default-source/ documents/decade-of-health-ageing/decade-ageing-proposal-en.pdf?sfvrsn=b0a7b5b1_12 [retrived: 14.09 .2019$]$.

${ }^{5}$ B.L. Neugarten, R.J. Havighurst, S.T. Tobin, Disengagement, Personality, and Life Satisfaction in Later Years, [w:] The Meanings of Age. Selected papers of B.L. Neugarten, red. D.A. Neugarten, Chicago 1996, s. 281-288. 
się do jego rozwoju i poczucia dobrostanu, strategia pasywności i wycofania w dłuższej perspektywie czasowej zagraża dobrostanowi seniora, przyczyniając się nie tylko do jego społecznej marginalizacji lub wykluczenia, lecz także szybszej degradacji fizycznej i psychicznej ${ }^{6}$.

Uwzględniając powyższe, współczesne programy zmierzające do rozwiązywania problemów starzejących się społeczeństw konstruowane są w paradygmacie „aktywnego starzenia się" definiowanego przez WHO jako „program poprawy warunków zdrowotnych, możliwości społecznej partycypacji i stopnia bezpieczeństwa ludzi starszych celem podniesienia jakości ich życia"7. Do podstawowych celów polityki „aktywnego starzenia się" zaliczane jest jak najdłuższe utrzymywanie przez seniora dobrej kondycji fizycznej i życiowej niezależności, zróżnicowanych form uczestnictwa społecznego (jak aktywność zawodowa, uczestnictwo w kulturze i konsumpcji, kontakty rodzinne i towarzyskie, uczestnictwo polityczne) i aktywności psychicznej (pielęgnowanie zainteresowań, poszukiwanie informacji czy aktywności edukacyjne). Realizację owych celów, także w odniesieniu do osób osamotnionych, niepełnosprawnych czy objętych programami ośrodków opiekunczych, umożliwiają współczesne technologie, wśród których, obok technologii asystujących, dużą rolę odgrywają IT.

Zarówno technologie informacyjne, jak i nowe media postrzega się jednak jako przynależne przede wszystkim młodej generacji, dla której są naturalnym środowiskiem wzrastania. Określa się ją jako cyfrowych tubylców. Przypisywane tej grupie atrybuty to przede wszystkim zżycie się i biegłość $\mathrm{w}$ posługiwaniu nowoczesnymi technologiami informacyjnymi i komunikacyjnymi wyrażane między innymi intensywnością wykorzystania i stopniem zanurzenia w cyberprzestrzeni. J. Morbitzer ${ }^{8}$ charakteryzuje także jej specyfikę, używając określenia pokolenie 7C i opisując cyfrowych tubylców jako: Connected (podłączonych), Communicating (komunikujących się), Computerized (skomputeryzowanych), Community-oriented, Content-centric (zorientowanych na swoje społeczności oraz samodzielnie tworzone i wybierane treści), Celebritized (łaknących zaistnienia publicznego) i always Clicking (nieustannie klikających).

Przeciwieństwem generacji 7C są cyfrowi imigranci, sytuowani w roli mało kompetentnych i zapóźnionych w technologicznym rozwoju outsiderów pokolenia doświadczającego cyfrowej marginalizacji i wykluczenia. Są to osoby starsze, wychowujące się w czasach przedinternetowych (przede

${ }^{6}$ K.J. Johnson, J.E. Mutchler, The Emergence of a Positive Gerontology: From Disengagement to Social Involvement, The Gerontologist, 2013, 54, 1, s. 93-100.

7 Active Ageing. A Policy Framework, WHO, Geneva 2002, s. 12.

${ }^{8}$ J. Morbitzer, O wychowaniu w świecie nowych mediów - zarys problematyki, Labor et Educatio, 2014, 2, s. 119-143. 
wszystkim przedstawiciele generacji baby-boomers), które dołączają do użytkowników cyberprzestrzeni, choć nie uzyskują biegłości posługiwania się jej środkami i zasobami w stopniu równym cyfrowym tubylcom ${ }^{9}$ Zróżnicowanie poziomu kompetencji obu wzmiankowanych generacji wiązane jest przy tym ze zjawiskiem „ludzkiej luki”. Pojęciem tym J.W. Botkin ${ }^{10}$ określa narastającą rozbieżność między dynamicznym rozwojem wiedzy i technologii a ludzkimi zdolnościami ich przyswajania w skali masowej. Za istotne czynniki owego procesu przyjmuje jednak nie tylko różnice generacyjne, lecz także nierówności społeczne i edukacyjne.

Jedną z konsekwencji współoddziaływań szybkiego rozwoju technologicznego i wzmiankowanych nierówności jest zjawisko technologicznego podziału, określanego też pojęciem cyfrowej luki. Termin ten odnoszony jest do nierówności w dostępie oraz poziomie wykorzystywania technologii informacyjnych przez różne grupy i zbiorowości społeczne ${ }^{11}$. Do przejawów omawianego zjawiska zaliczane są zróżnicowanie dostępu do technologii, umiejętności ich użytkowania oraz korzyści uzyskiwanych przez poszczególnych użytkowników ${ }^{12}$. Jego uwarunkowania obejmują czynniki o charakterze zewnętrznym i wewnętrznym ${ }^{13}$. Do pierwszej kategorii zaliczane są nierówności społeczne i ekonomiczne, zapóźnienia cywilizacyjne, niedorozwój infrastruktury, niski poziom edukacji, czy uwarunkowania polityczne i kulturowe. W grupie drugiej sytuują się cechy indywidualne o charakterze demograficznym (jak wiek, płeć, wykształcenie, niepełnosprawność, niski dochód, czy trudna sytuacja mieszkaniowa), osobowościowym (jak poziom inteligencji, indywidualne motywacje, styl życia) i kompetencyjnym, czyli poziom biegłości w posługiwaniu się $\mathrm{IT}^{14}$. Poszczególni użytkownicy różnią się sposobem posługiwania się nowymi mediami w życiu codziennym. Istotną rolę odgrywają przy tym czynniki motywacyjne, określające, kiedy, jak, w jakim celu, w jaki sposób oraz w jakim stopniu i zakresie podmiot skłonny jest wykorzystywać możliwości współczesnych technologii (Siverstone $\mathrm{i}$ in., 1996).

\footnotetext{
${ }^{9}$ M.R. Jabłońska, Człowiek w cyberprzestrzeni. Wprowadzenie do psychologii Internetu, Łódź 2018.

${ }^{10}$ J.W. Botkin, No Limits to Learning: Bridging the Human Gap: The Report to the Club of Rome, Oxford 2014.

${ }^{11}$ B.M. Compaine, The digital divide: Facing a crisis or creating a myth? Cambridge 2001.

${ }^{12}$ A. Scheerder, A.J.A.M. van Deursen, J.A.G.M. van Dijk, Determinants of Internet skills, uses and outcomes. A systematic review of the second-and third-level digital divide, Telematics and Informatics, 2017, 34(8), s. 1607-1624.

${ }^{13}$ M. Regnedda, G.W. Muschert (red.), The Digital Divide. The Internet and social inequalities in international perspective, New York 2013.

${ }_{14}$ A. Scheerder, A.J.A.M. van Deursen, J.A.G.M. van Dijk, Determinants of Internet skills, uses and outcomes.
} 
Do czynników tych zaliczamy przede wszystkim wpływ otoczenia społecznego, cel podejmowanych aktywności, szacunki oczekiwanych korzyści i nakładów, jak również indywidualne potrzeby, ukształtowane nawyki i styl życia danej osoby ${ }^{15}$. Kształtują się one w toku rozwoju jednostki w określonym kontekście społeczno-kulturowym, stanowiąc zatem pochodną doświadczenia pokoleniowego, pojmowanego jako wspólnota uczestnictwa w pewnej fazie rozwoju społeczno-historycznego oraz związanego z tym uczestnictwem stanu świadomości ${ }^{16}$.

Zasadność odwoływania się do koncepcji pokolenia w badaniach nad aktywnością seniorów w cyberprzestrzeni potwierdzają badania B. Niehaves i R. Plattfaut, czy M. Grubb, A. Tymuli, S. Gilaie-Dotan, P. Glimchera, I. Levy' ego $^{17}$, identyfikując różnice pokoleniowe w posługiwaniu się Internetem. Podjęte porównania wskazują między innymi na:

- odmienność preferencji i postaw seniorów oraz millenialsów wobec podejmowania ryzyka w cyberprzestrzeni (co tłumaczy np. większą niechęć seniorów do internetowej bankowości);

- odmienność preferencji odnośnie form utrzymywania kontaktów z innymi ludźmi (seniorzy w większym stopniu, niż ich wnuki, preferowali kontakty bezpośrednie), oraz

- większą selektywność seniorów w doborze aktywności podejmowanych $\mathrm{w}$ Internecie (seniorzy okazywali zainteresowanie Internetem przede wszystkim ze względu na możliwości komunikowania się z rodziną i przyjaciółmi, wyszukiwania informacji oraz uzyskiwania pomocy).

Odmienność funkcjonowania internautów reprezentujących różne pokolenia sugerują także badania nad kompetencjami cyfrowymi. Treści owych kompetencji znacząco wykraczają poza techniczną biegłość w posługiwaniu się cyfrowymi narzędziami i zasobami. E. Klecun ${ }^{18}$ wskazuje, iż podstawę ich stanowią złożone umiejętności, do których zaliczają tradycyjne umiejętności czytania ze zrozumieniem i poprawnego wypowiadania się pisemnego, umiejętność obsługi komputera, umiejętność poszukiwania i przetwarzania informacji oraz umiejętność wielostronnego i krytycznego podejścia do no-

15 V. Venkatesh, J.Y.L. Thong, X. Xu, The Unified Theory of Acceptance and Use of Technology. A Synthesis and the Road Ahead, Journal of the Association for Information Systems, 2016, 17, 5, s. 328-376.

16 H.M. Griese, Socjologiczne teorie młodzieży, Kraków 1996, s. 84-86.

17 B. Niehaves, R. Plattfaut, Internet adoption by the elderly: employing IS technology acceptance theories for understanding the age-related digital divide, European Journal of Information Systems, 2014, 23, 6, s. 708-726; M. Grubb i in., Neuroanatomy accounts for age-related changes in risk preferences, Nature Communications, 2016, 7, [13822]. https://doi.org/10.1038/ncomms13822 [retrived: 09.09.2019].

18 E. Klecun, Bringing lost sheep into the fold: questioning the discourse of the digital divide, Information Technology \& People, 2008, 21, 3, s. 267-282. 
wych mediów. Niedostatki w powyższym zakresie sprzyjają przy tym cyfrowemu wykluczeniu w stopniu nie mniejszym, niż brak motywacji, zła sytuacja ekonomiczna, czy brak wsparcia ze strony otoczenia społecznego ${ }^{19}$.

W świetle powyższego, błędne wydaje się założenie, iż generacyjne różnice kompetencji cyfrowych mają charakter ilościowy, a pokolenie cyfrowych tubylców cechuje się ich wyższym poziomem. Podejmowane analizy wykazują raczej różnice o charakterze jakościowym. Pokolenie cyfrowych tubylców cechuje wprawdzie większy stopień zanurzenia w cyberprzestrzeni i sprawność techniczna, jednak generują one zjawisko określane przez J. Morbitzera pojęciem mediotyzmu. Składają się nań powierzchowność podejmowanych aktywności, wąski zakres zainteresowań, mała selektywność i brak krytycyzmu wobec pozyskiwanych informacji, deficyty kompetencji formalnych (ograniczenia zdolności analizy i syntezy, zapamiętywania, przetwarzania i uogólniania), ograniczenie form aktywności intelektualnej, niski stopień refleksyjności oraz ograniczenia zdolności komunikowania się w kodzie rozwiniętym. Wzmiankowanym niedostatkom towarzyszy przy tym paradoksalna rozbieżność między silną potrzebą bycia w grupie oraz stosunkowo niskim poziomem kompetencji społecznych i emocjonalnych ${ }^{20}$.

Wzmiankowaną specyfikę J. Morbitzer ${ }^{21}$ wiąże z dużą dostępnością zdobyczy świata cyfrowego, osłabieniem wychowawczej roli rodziny oraz roli szkoły jako instytucji kształtującej kompetencje formalne, społeczne i humanistyczne, przenoszeniem się grup rówieśniczych do cyberprzestrzeni oraz wzmożonymi oddziaływaniami nowych mediów będących znaczącą agencją socjalizującą młodego pokolenia. Odmiennie kształtowały się natomiast warunki socjalizacji pokolenia seniorów. Istotnymi elementami doświadczenia pokoleniowego tej grupy były wydarzenia drugiej połowy wieku XX: kształtująca kompetencje społeczne i emocjonalne grupa podwórkowa, stosunkowo wysoki poziom kształcenia kładący nacisk na rozwój kompetencji formalnych i komunikacyjnych, pobudzająca niezależność rewolta młodzieżowa i rewolucja obyczajowa lat 60., doświadczenie samodzielnego i bezpośredniego odkrywania świata w latach 70., kontestacja polityczna i solidarność społeczna lat 80., czy przedsiębiorczość wymuszona warunkami transformacji przełomu wieków.

Ostatnie dziesięciolecie wieku XX to także cyfrowy debiut pokolenia współczesnych seniorów, jak również okres inicjujący cyfrowe podziały. Początki In-

${ }^{19}$ G. Georgiu, General IT Literacy: A Research Report of a Survey of the British Population on Computer Usage, The British Computer Society 2004; R. Jedlińska, Wykluczenie cyfrowe w Polsce na tle Unii Europejskiej, Ekonomiczne Problemy Usług, 2018, 2(131), s. 225-236.

${ }^{20} \mathrm{~J}$. Morbitzer, Wspótczesna przestrzeń obecności człowieka - między realnością a wirtualnościa, Zeszyty Naukowe Wyższej Szkoły Humanitas. Pedagogika, 2016, 13, s. 59-68.

${ }^{21} \mathrm{~J}$. Morbitzer, O wychowaniu w świecie nowych mediów, s. 119-143. 
ternetu w Polsce przypadają na lata 80. minionego wieku. Błędem jest zatem przyjmowanie, iż obecność współczesnych 70-latków w cyberprzestrzeni jest przejawem ich cyfrowej imigracji. Podobnie jak bezzasadne wydaje się założenie cyfrowej marginalizacji definiowanej w kategoriach odmienności form wykorzystywania możliwości cyberprzestrzeni. Różnicująca obydwa pokolenia specyfika warunków socjalizacji i treści kształcenia niewątpliwie ma istotne znaczenie dla kształtowania się technicznej biegłości w posługiwaniu się współczesnymi środkami technologii informacyjnych. Stopień, formy i zakres podejmowanych aktywności są jednak kwestią indywidualnych decyzji podmiotów wynikających z ich potrzeb i stylu życia. W powyższym kontekście rezygnacja $z$ określonych form aktywności internetowych wydaje się być nie tyle przejawem deficytu kompetencji cyfrowych, co aktem niezależności autonomicznego podmiotu świadomie kształtującego swoje życie.

\section{Przedmiot i metoda podjętych analiz}

Przedmiotem podjętych analiz była aktywność polskich seniorów w cyberprzestrzeni. Poszukiwano przy tym odpowiedzi na pytanie: Czy polskich seniorów ogólnie cechuje zjawisko wykluczenia cyfrowego czy raczej należy mówić o wewnętrznym zróżnicowaniu danej grupy wiekowej, a jeśli TAK, to jakie znaczenie $w$ tym procesie odgrywa edukacja?

Objęte analizą dane pochodzą z badań prowadzonych przez GUS, opublikowanych w latach 2015 - 2018. Jest to materiał statystyczny oparty na dużych, kilkudziesięciotysięcznych próbach, o wiarygodnej metodologii uzgadnianej z Eurostatem. Można zatem przyjąć, że mają duży walor prognostyczny. Uzupełnieniem analiz statystycznych GUS był raport CBOS. Choć badania przeprowadzono na mniejszej populacji, to jest to instytucja badawcza o wiarygodniej, wieloletniej renomie i wiarygodnych standardach metodologicznych. Ponadto, dla potrzeb badawczych odwołano się przy tym do metody opartej na zestawianiu i analizie danych już istniejących ${ }^{22}$.

\section{Analiza danych empirycznych}

\section{Wiek a intensywność korzystania z Internetu}

Dominującym wątkiem dyskursu dotyczącego osób starszych jest, obok problemów zapewnienia im opieki, także ich wykluczenie cyfrowe. Kontrastując seniorów z pokoleniem cyfrowych tubylców, przypisuje się tym pierwszym brak umiejętności i chęci korzystania z Internetu oraz funkcjonowania w Sieci.

${ }^{22}$ E. Babbie, The Practice of Social Research, Boston 2015. 
Potoczny ogląd stanu rzeczy zdaje się potwierdzać ten stereotyp. Materiał statystyczny zaprezentowany w tabeli 1 zdaje się jednak podważać ten mit.

Tabela 1

Średnia liczba godzin tygodniowo spędzana w Internecie przez dorosłych Polaków według wieku

\begin{tabular}{|c|c|c|c|c|c|}
\hline \multicolumn{7}{|c|}{ Respondenci według wieku } \\
\hline $18-24$ & $25-34$ & $35-44$ & $45-54$ & $55-64$ & powyżej 65 lat \\
\hline \multicolumn{7}{|c|}{ Ilość czasu poświęconego na korzystanie z Internetu w godzinach } \\
\hline $20^{1}$ & 16 & 12 & 9 & 9 & 8 \\
\hline
\end{tabular}

Uwaga:

${ }^{1}$ wyniki badań zaokrąglono, według obowiązujących standardów, do pełnych godzin.

Źródło: Korzystanie z Internetu, Komunikat z badań CBOS, nr 95/2019, s. 9.

Okazuje się, że spadek zaangażowania w aktywności internetowej pojawia się we wcześniejszym okresie życia - około 35. roku życia, ze względu na pojawiające się coraz większe obowiązki zawodowe i rodzinne. Natomiast, od tego momentu do wieku senioralnego obserwujemy zbliżony poziom zaangażowania czasowego, co uzasadnia twierdzenie, iż seniorzy nie są mniej aktywni w cyberprzestrzeni niż osoby młodsze.

\section{Wykształcenie a użytkowanie Internetu}

Do ważnych zmiennych socjodemograficznych zaliczamy, obok wieku, także wykształcenie. Jak już wskazywaliśmy powyżej, jest ono czynnikiem o istotnym znaczeniu dla kształtowania się umiejętności formalnych, ważnych z punktu widzenia kształtowania się kompetencji cyfrowych. Dane zgromadzone przez GUS dowodzą także, iż jest to czynnik decydujący o zdolności i/lub motywacji podmiotu do korzystania z możliwości i zasobów internetowych (tab. 2).

Tabela 2

Korzystanie z Internetu przez dorosłych Polaków według wieku i poziomu wykształcenia ( $w \%)$

\begin{tabular}{|c|c|c|c|}
\hline \multirow{2}{*}{$\begin{array}{c}\text { Poziom } \\
\text { wykształcenia }\end{array}$} & Respondenci według wieku \\
\cline { 2 - 4 } & 16-24 lat & 25-54 lat & powyżej 55 lat \\
\cline { 2 - 4 } & 100,0 & $\mathrm{w} \%$ & 92,1 \\
\hline Wyższy & 99,7 & 59,8 & 13,5 \\
\hline Niższy & &
\end{tabular}

Źródło: Wykorzystanie technologii informacyjno-komunikacyjnych w gospodarstwach domowych w 2018 roku - część 2, http:/ / www.ict_gospodarstwa_domowe_2017_cz_2, [dostęp: 05.12.2019]. 
Jak wskazuje powyższe zestawienie, poziom edukacji nie różnicuje w zasadzie poziomu korzystania $\mathrm{z}$ Internetu jedynie $\mathrm{w}$ grupie osób najmłodszych (16 - 24 lata). Z wiekiem zaczyna być jednak coraz bardziej istotny. Osoby cechujące się wyższym poziomem wykształcenia korzystają z Internetu przez całe życie, natomiast legitymujący się niskim poziomem wykształcenia $\mathrm{z}$ wiekiem tracą zainteresowanie tą formą uczestnictwa. Odsetki użytkowników Internetu wraz z wiekiem spadają w sposób drastyczny. Samo wyjście z okresu młodzieżowego - po ukończeniu 25. roku życia - powoduje spadek zainteresowania Internetem o 43 punkty procentowe. Wiek okołoemerytalny redukuje zaś zbiorowość internautów o kolejne 44 punkty, dając poziom niewiele ponad 13\% członków danej zbiorowości. Pozwala to stwierdzić, iż zasadniczym czynnikiem różnicującym stopień wykorzystania Internetu jest nie wiek, a poziom edukacji podmiotu.

\section{Wiek a sposób wykorzystywania Internetu}

Internet jest środowiskiem o zróżnicowanych zasobach i funkcjach, umożliwiającym swoim użytkownikom realizację dość licznych celów. W świetle istniejących badań, do najpopularniejszych celów posługiwania się Internetem w Polsce zalicza się:

- poszukiwanie informacji - 69,2\%;

- komunikowanie się - 67,5\%;

- korzystanie z usług określanych mianem „e-zdrowie” - 49,5\%.

Z mniejszym zainteresowaniem spotyka się korzystanie z usług i serwisów online - około 23\% badanych Polaków. Natomiast z zapośredniczonego cyfrowo uczestnictwa w życiu społecznym (którego nie należy mylić z korzystaniem z portali społecznościowych) korzysta jedynie 9,5\% respondentów ${ }^{23}$.

Wzmiankowane cele eksponowane są we wszystkich grupach wiekowych. W grupie seniorów (powyżej 65 lat) zakres zainteresowania poszczególnymi funkcjami był taki sam, jak w grupie osób młodszych. Odmiennie kształtował się jednak jego stopień. Interesowała ich również komunikacja, dostęp do informacji i usługi określane mianem „e-zdrowie” - odpowiednio 22,25 i $19 \%{ }^{24}$.

Wyrażano także niskie zainteresowanie usługami online i internetowymi formami uczestnictwa w życiu społecznym - odpowiednio 6 i $3 \%{ }^{25}$.

Z pozoru możemy mówić o towarzyszącym procesom starzenia się zaniku zainteresowania poszczególnymi funkcjami Internetu. Włączenie do analizy czynnika wykształcenia zmienia jednak obraz istniejącej sytuacji (tab. 3).

${ }^{23}$ Wykorzystanie technologii informacyjno-komunikacyjnych $w$ gospodarstwach domowych w 2018 roku - część 2, http:/ / www.ict_gospodarstwa_domowe_2017_cz_2, [dostęp: 05.12.2019].

${ }^{24}$ Tamże.

${ }^{25}$ Tamże. 
Tabela 3

Poziom wykształcenia a cele korzystania z Internetu przez seniorów (w \%)

\begin{tabular}{|l|c|c|c|c|c|}
\hline \multirow{2}{*}{$\begin{array}{c}\text { Poziom } \\
\text { wykształ- } \\
\text { cenia }\end{array}$} & $\begin{array}{c}\text { komuniko- } \\
\text { wanie się }\end{array}$ & $\begin{array}{c}\text { dostęp } \\
\text { do infor- } \\
\text { macji }\end{array}$ & $\begin{array}{c}\text { usługi } \\
\text { e-zdrowie }\end{array}$ & $\begin{array}{c}\text { partycypa- } \\
\text { cja społecz- } \\
\text { na }\end{array}$ & $\begin{array}{c}\text { usługi } \\
\text { online }\end{array}$ \\
\cline { 2 - 6 } & \multicolumn{5}{|c|}{ w \% } \\
\hline Niski & 5,8 & 7,4 & 2,0 & 0,4 & 0,4 \\
\hline Wysoki & 74,7 & 79,3 & 61,9 & 13,6 & 34,5 \\
\hline
\end{tabular}

Źródło: opracowanie własne na podstawie: Wykorzystanie technologii informacyjno-komunikacyjnych.

Przedstawiony powyżej materiał statystyczny wskazuje, że czynnikiem decydującym o zakresie korzystania z możliwości Internetu jest nie wiek, a poziom wykształcenia, które różnicowało zachowania respondentów we wszystkich formach aktywności. Osoby o wyższym wykształceniu, niezależnie od wieku, częściej korzystały z możliwości oferowanych przez cyberprzestrzeń, niż osoby o wykształceniu niższym.

Zainteresowanie tymi samymi formami aktywności internetowych nie oznacza jednak tego samego stopnia zaangażowania. Jak bowiem wskazują dane, osoby w wieku produkcyjnym uprawiają określone formy aktywności bardziej intensywnie, niż seniorzy (tab. 4).

Tabela 4

Wiek a cele korzystania z Internetu przez osoby z wyższym wykształceniem (w \%)

\begin{tabular}{|l|c|c|c|c|c|}
\hline \multirow{2}{*}{ Wiek } & \multicolumn{5}{|c|}{ Forma aktywności w Internecie } \\
\cline { 2 - 6 } & $\begin{array}{c}\text { komuniko- } \\
\text { wanie się }\end{array}$ & $\begin{array}{c}\text { dostęp do } \\
\text { informacji }\end{array}$ & $\begin{array}{c}\text { usługi } \\
\text { e-zdrowie }\end{array}$ & $\begin{array}{c}\text { partycy- } \\
\text { pacja spo- } \\
\text { feczna }\end{array}$ & $\begin{array}{c}\text { usługi } \\
\text { online }\end{array}$ \\
\cline { 2 - 6 } & \multicolumn{5}{|c|}{ w \% } \\
\hline $\begin{array}{l}\text { Osoby w wieku } \\
\text { produkcyjnym }\end{array}$ & 100,0 & 96,4 & 72,7 & 17,7 & 49,3 \\
\hline Seniorzy & 74,7 & 79,3 & 61,9 & 13,6 & 34,5 \\
\hline
\end{tabular}

Źródło: opracowanie własne na podstawie: Wykorzystanie technologii informacyjno-komunikacyjnych.

Powyższe zestawienie wskazuje wprawdzie, iż hierarchia zainteresowań w obu porównywanych grupach jest identyczna. Osoby starsze wykazują jednak dużo mniejsze zaangażowanie w każdą z nich. Wzmiankowany spadek trudno tłumaczyć zanikaniem wraz z wiekiem kompetencji cyfrowych (gdyż, 
jak wskazywały pozostałe tabele, kompetencje te utrzymują się do późnej starości). Nasuwa się zatem przypuszczenie zadziałania czynnika pośredniczącego, który należałoby ustalić w trakcie dalszych analiz.

\section{Wnioski}

Podjęte analizy zaprzeczają tezie cyfrowego wykluczenia pokolenia seniorów. Różnicujący wpływ wieku zaznacza się jedynie do okresu stabilizacji życiowej (ok. 35. r.ż.), kiedy to młodsze pokolenie jest znacznie bardziej aktywne niż pokolenie seniorów oraz w okresie późnej starości (po 80. r.ż.). W pozostałych okresach życia decydujące znaczenie dla obecności w cyberprzestrzeni ma czynnik wykształcenia. Poziom wykształcenia determinuje także cele realizowane za pośrednictwem Internetu. We wszystkich grupach wiekowych jako najważniejsze wskazywano poszukiwanie informacji i komunikowanie się. U osób z niższym poziomem wykształcenia z wiekiem zainteresowanie tymi działaniami jednak się zmniejszało. Czynnik wieku nie różnicował również stopnia zaangażowania badanych osób w internetowo zapośredniczone formy działalności społecznej i politycznej. We wszystkich grupach wiekowych odsetek osób zaangażowanych był bardzo niski.

Reasumując, należy stwierdzić, iż wbrew popularnym poglądom, grupa seniorów nie jest zagrożona wykluczeniem informacyjnym. Część z nich przypuszczalnie doświadcza mniejszych lub większych niedostatków posiadanych kompetencji. Trudno ich jednak uznawać za cyfrowych imigrantów. Przy jednakowym, wyższym poziomie wykształcenia czynnik wieku nie różnicuje obecności podmiotów w cyberprzestrzeni. Sposób podejścia do Internetu jest jednak w obu pokoleniach zróżnicowany. Seniorów cechuje mianowicie większy dystans, wybiórczość i utylitaryzm, niż młodych dorosłych. Okazując większą niezależność wobec kultury, nie starają się imitować stylu bycia w Internecie swoich wnuków. Dostosowują natomiast swoje aktywności internetowe do odczuwanych potrzeb i oczekiwań.

\section{BIBLIOGRAFIA}

Active Ageing. A Policy Framework, WHO, Geneva 2002.

Babbie E., The Practice of Social Research, CENGAGE Learning, Boston 2015.

Błeszyńska K., Wolność $i$ władza w sieci, [w:] Potencjały relacji sit w cyfrowym społeczeństwie wiedzy, red. L. Zacher, Poltext, Warszawa 2018.

Botkin J.W., No Limits to Learning: Bridging the Human Gap: The Report to the Club of Rome, Pergamon Press, Oxford 2014. 
Bradbrook G., Fisher J., Digital Equality: Reviewing Digital Inclusion Activity and Mapping the Way Forwards, 2004, Citizens online;

http//www.citizensonline.org.uk/site/media/documents/939_DigitalEquality1.pdf [retrived 14.09.2019].

Compaine B.M., The digital divide: Facing a crisis or creating a myth? Massachusetts Institute of Technology Press, Cambridge 2001.

Decade of Healthy Aging (2019a). WHO; https://www.who.int/docs/default-source/ documents / decade-of-health-ageing/decade-ageing-proposal-en.pdf?sfvrsn=b0a7b5b1_12 [retrived: 14.09.2019].

Decade of Healthy Ageing (2020-2030), (2019b). WHO; https:/ / www.who.int/ageing/decade-of-healthy-ageing [retrived: 14.09.2019].

Dijk van J.A., A theory of the digital divide, [w:] The Digital Divide. The Internet and social inequalities in international perspective, red. M. Regnedda, G.W. Muschert, Routledge, New York 2013.

GDP percapita in PPShttps:/ / ec.europa.eu/eurostat/tgm/table.do?tab=table\&plugin=1\& language $=$ en\&pcode $=$ tec00114 [retrived: 23.07.2019].

Georgiou G., General IT Literacy: A Research Report of a Survey of the British Population on Computer Usage, The British Computer Society 2004.

Griese H.M., Socjologiczne teorie młodzieży, Oficyna Wydawnicza Impuls, Kraków 1996.

Grubb M.A., Tymula A., Gilaie-Dotan S., Glimcher P., Levy I., Neuroanatomy accounts for age-related changes in risk preferences, Nature Communications, 2016, 7, [13822]. https:/ / doi.org/10.1038/ncomms13822 [retrived: 09.09.2019].

Hill R., Beynon-Davies P., Williams M.D., Older people and internet engagement. Acknowledging social moderators of internet adoption, access and use, Information Technology \& People, 2008, 21, 3.

Hynes D., Rommes E., Fitting the Internet into our lives: internet courses for disadvantaged users, [w:] Domestication of Media and Technologies, red. T. Berker, M. Hartmann, Y. Punie, Open University Press, Maidenhead 2005.

Jabłońska M.R., Człowiek w cyberprzestrzeni. Wprowadzenie do psychologii Internetu, Wydawnictwo Uniwersytetu Łódzkiego, Łódź 2018.

Jedlińska R., Wykluczenie cyfrowe w Polsce na tle Unii Europejskiej, Ekonomiczne Problemy Usług, 2018, 2(131).

Johnson K.J., Mutchler J.E., The Emergence of a Positive Gerontology: From Disengagement to Social Involvement, The Gerontologist, 2013, 54, 1.

Klecun E., Bringing lost sheep into the fold: questioning the discourse of the digital divide, Information Technology \& People, 2008, 21, 3.

Korzystanie z Internetu, CBOS, nr 95, Warszawa 2019.

Morbitzer J., O wychowaniu w świecie nowych mediów - zarys problematyki, Labor et Educatio, 2014, 2.

Morbitzer J., Wspótczesna przestrzeń obecności człowieka - między realnościa a wirtualnościa, Zeszyty Naukowe Wyższej Szkoły Humanitas. Pedagogika, 2016, 13.

Nauka i technika w 2017, GUS, Warszawa - Szczecin 2019; https://stat.gov.pl/obszary-tematyczne/nauka-i-technika-spoleczenstwo-informacyjne/nauka-i-technika/nauka-i-technika-w-2017-roku,1,14.html [retrived: 20.08.2019].

Neugarten B.L., Havighurst R.J., Tobin S.T., Disengagement, Personality, and Life Satisfaction in Later Years, [w:] The Meanings of Age. Selected papers of B.L. Neugarten, red. D.A. Neugarten, University of Chicago Press, Chicago 1996. 
Niehaves B., Plattfaut R., Internet adoption by the elderly: employing IS technology acceptance theories for understanding the age-related digital divide, European Journal of Information Systems, 2014, 23, 6 .

Phillipson Ch., Capitalism and the Construction of Old Age, Macmillan, London 1982.

Quality of life. Facts and Views, Publications Office of the European Union, Luxembourg 2015.

Regnedda M., Muschert G.W. (red.), The Digital Divide. The Internet and social inequalities in international perspective, Routledge, New York 2013.

Scheerder A., van Deursen A.J.A.M., van Dijk J.A.G.M., Determinants of Internet skills, uses and outcomes. A systematic review of the second-and third-level digital divide, Telematics and Informatics, 2017, 34(8).

The 2018 Ageing Report: Underlying Assumptions and Projection Methodologies, DirectorateGeneral for Economic and Financial Affairs, European Commission, Brussel 2018.

Tymula A., Rosenberg Belmaker L.A., Ruderman L., Glimcher P.W., Levy I., Like cognitive function, decision making across the life span shows profound age-related changes, [w:] The Proceedings of the National Academy of Sciences (PNAS), red. M.S. Gazzaniga, PNAS, October 15, 2013, 110(42).

Venkatesh V., Thong J.Y.L., Xu X., The Unified Theory of Acceptance and Use of Technology. A Synthesis and the Road Ahead, Journal of the Association for Information Systems, $2016,17,5$.

Wykorzystanietechnologiiinformacyjno-komunikacyjnychwgospodarstwachdomowychw2018 roku - część 2, http:/ / www.ict_gospodarstwa_domowe_2017_cz_2, [dostęp: 05.12.2019]. 